\title{
KENDALA DAN OPTIMALISASI PELAKSANAAN UNDANG- UNDANG TERKAIT DENGAN OTONOMI DAERAH
}

\author{
Irlandi Paradizsa Dirja \\ Universitas Indonesia, Indonesia \\ irlandiparadizsa@gmail.com
}

\begin{abstract}
Abstrak: Dengan diberlakukannya otonomi daerah di Indonesia, maka urusan pembangunan pun tidak lagi dijalankan satu arah dari Pemerintah Pusat. Keberadaan dari otonomi daerah ini memberikan kendali kepada Pemerintah Daerah untuk mengatur daerahnya masing-masing. Namun, pelaksanaan dari otonomi daerah yang terkesan terburu-buru menimbulkan beberapa kendala dalam pelaksanaannya. Kendala yang dihadapi meliputi ketidakmerataan sumber daya manusia, berkembangnya kesenjangan antar daerah, dan sulitnya menyinkronkan pembangunan daerah dan pusat. Sehingga, untuk mengurangi permasalahan yang muncul tersebut, maka perlu dilakukan seleksi atau rekrutmen ketat terhadap sumber daya manusianya dan dilakukan pendampingan secara seksama terhadap proses pembangunan di daerah.
\end{abstract}

Kata kunci: Otonomi Daerah, Demokrasi, Kendala, Optimalisasi, Sumber Daya Manusia

\section{PROBLEM FROM AND OPTIMIZATION FOR THE IMPLEMENTATION OF THE LAWS IN REGARDS TO REGIONAL AUTONOMY}

\begin{abstract}
With the enactment of the regional autonomy in Indonesia, some of the development affairs are no longer implemented one-way from the Central Government. The existence of regional autonomy has given some controls towards the Regional Government to manage their region. However, the implementation of regional autonomy that seems to be rushed has resulted in the emergence of problems during its execution. The issues that emerged are the discrepancy of human resources between regions, regional inequality, and the difficulty in synchronizing the development between the area and central. To reduce the number of problems that arose because of that, there should be a strict recruitment process for human resources and implementation of a careful accompaniment for the development process in the region.
\end{abstract}

Keywords: Regional Autonomy, Democracy, Problems, Optimization, Human Resources

\section{PENDAHULUAN}

Pasca reformasi dilaksanakan pada tahun 1997, dengan semangat demokrasi yang menggebugebu, di tahun 2004 telah dikeluarkan Undang-Undang Nomor 32 Tahun 2004 terkait dengan Otonomi Daerah. Secara prinsip dan teori, otonomi daerah merupakan salah satu dasar pelaksanaan demokrasi. Di mana kuasa atas pemerintahan itu diletakan agar semakin dekat dengan masyarakat. Semakin dekat kuasa tersebut diberikan kepada masyarakat, itulah tujuan dari demokrasi. Agar masyarakat bisa berpartisipasi dalam urusan pengelolaan pemerintahan. Namun, karena kendala terbesar dari pelaksanaan demokrasi adalah kemasifan jumlah penduduk yang ada di bumi sekarang ini. Pelaksanaan demokrasi langsung oleh masyarakat merupakan suatu kemustahilan yang masih terus diusahakan agar bisa dilaksanakan. Otonomi daerah inilah merupakan salah satu usaha untuk memperjuangkan bagaimana demokrasi itu bisa dijalankan. Walaupun sesungguhnya otonomi daerah masih mengandalkan pemerintah daerahnya, namun bisa menjadi semangat awal menuju modernisasi demokrasi yang terus berkembang.

Setelah sepuluh tahun bertahan sebagai aturan terkait pelaksanaan Otonomi Daerah, pada tahun 2014 keluar Undang-Undang baru terkait pengelolaan otonomi daerah itu sendiri (Negara, 2015). Undang-Undang No. 32 Tahun 2004 dipecah menjadi tiga peraturan perundang-undangan terkait dengan substansi besarnya (Negara, 2015). Pertama terkait dengan penyelenggaraan 
pemerintahan daerah diatur dalam Undang-Undang No. 23 Tahun 2014 tentang Pemerintah Daerah. Kedua terkait dengan pemilihan Kepala Daerah yang diatur dalam Undang-Undang Nomor 22 Tahun 2014-yang kemudian diganti dengan Undang-Undang Nomor 1 Tahun 2015 (Negara, 2015). Ketiga adalah terkait dengan Desa yang diatur dalam Undang-Undang Nomor 6 Tahun 2014 (Negara, 2015). Pemecahan Undang-Undang Nomor 32 Tahun 2004 menjadi tiga substansi besar juga merupakan sebuah usaha lanjutan untuk memodernisasikan demokrasi dan semakin mendekatkan kuasa pemerintahan tersebut kepada masyarakat. Hal ini tercermin dengan diterbitkannya Undang-Undang Desa yang merupakan usaha untuk mengatur terkait Pemerintah Desa yang diharapkan bisa menjadi garda terdepan dalam proses pembangunan nasional (Negara, 2015). Hubungan antara kekuasaan dengan masyarakat akan semakin dekat ketika kuasa atas pemerintah atas desa itu jelas diatur hak dan kewajibannya sehingga masyarakat bisa berpartisipasi secara aktif di dalam pembangunan. Hal ini dikarenakan yang betul-betul memahami suatu permasalahan adalah masyarakat itu sendiri. Sehingga, pembangunan yang tepat sasaran sewajarnya harus bisa melibatkan masyarakat secara langsung. Penguatan desa merupakan salah satunya.

Bila dilihat dari pembahasan tersebut dapat diketahui bahwa pengaturan terhadap pelaksanaan otonomi daerah itu terus berkembang. Pada era Orde Baru, kuasa tertinggi berada di tangan pemerintah pusat. Masyarakat akan semakin kesulitan untuk berpartisipasi dalam proses pembangunan karena hubungan yang jauh antara masyarakat dengan pemerintah pusat. Namun, dengan terjadinya reformasi dan terkobarkannya semangat demokrasi di Indonesia, dikeluarkan juga Undang-Undang Nomor 32 Tahun 2004 yang mengatur tentang Pemerintah Daerah. Sehingga hubungan antara masyarakat setidaknya menjadi lebih dekat bila dibandingkan dengan sebelumnya. Lalu, dengan diterbitkannya tiga paket Undang-Undang yang berkaitan dengan otonomi daerah tersebut—salah satu utamanya adalah Undang-Undang tentang Desa-pada tahun 2014 dan 2015 semakin mendekatkan hubungan antara masyarakat dengan kekuasaan. Bila ditinjau dari pergerakan alur tersebut, dapat dilihat bahwa sesungguhnya demokrasi dan otonomi daerah merupakan sebuah konsep dinamis yang terus berkembang — apalagi di Indonesia.

Demokrasi dan otonomi daerah sebagai konsep dan ide yang terus berkembang dan bergerak secara dinamis, menunjukkan bahwa kedua hal tersebut bukan lah konsep yang tertutup dari perbaikan. Karena pada pelaksanaannya pun, pelaksanaan demokrasi dan otonomi daerah ini bukan tidak luput dari kesalahan. Ada banyak hal yang masih bisa dikembangkan dan diperbaiki agar bisa terus memodernisasikan atau memajukan konsep dan ide tentang demokrasi dan otonomi daerah, sehingga bisa semakin dekat dengan pelaksanaan demokrasi secara langsung yang tidak hanya baik secara teori, namun juga berjalan dengan baik di lapangan. Oleh karena itu, pada tulisan ini akan dibahas secara lebih lanjut mengenai bagaimana permasalahanpermasalahan yang terjadi atas pelaksanaan demokrasi dan otonomi daerah sekarang ini. Lalu kemudian hal-hal apa saja yang bisa ditingkatkan atau dioptimalkan sehingga prinsip demokrasi dan otonomi daerah bisa dijalankan secara utuh. Permasalahan yang dibahas pada tulisan ini akan diulas menggunakan kacamata atau paradigma ekonomi kelembagaan. Di mana akan dilihat aspek keinstitusiannya berdasarkan prinsip-prinsip ekonomi yang berkembang.

\section{METODE PENELITIAN}

Penelitian ini yang dilakukan dalam tulisan ini bersifat kualitatif dengan menggunakan metode konten analisis. Menurut (Aspers \& Corte, 2019) yang dimaksud dengan penelitian kualitatif merupakan sebuah penelitian yang dilakukan menggunakan proses iterasi di mana peningkatan pemahaman terhadap suatu konsep ilmiah itu terjadi akibat ditemukannya perbedaan baru akibat 
semakin mendekati terhadap kebenaran atas fenomena yang dipelajari. Selain itu, Bryman (1988) menjelaskan bahwa karakteristik dari penelitian kualitatif sendiri adalah (1) melihat suatu kejadian dari perspektif suatu entitas yang subjektif; (2) deskripsi rinci atas suatu kejadian; (3) konteks atas suatu kejadian; (4) proses terjadinya kejadian tersebut; (5) fleksibilitas dan ketidakstrukturan dalam memahami kejadian tersebut; (6) teori dan konsep. Sehingga penelitian yang dilakukan dalam tulisan ini berusaha untuk memahami kembali terkait dengan pelaksanaan dari otonomi daerah di Indonesia secara kualitatif sebagaimana penjelasan sebelumnya. Penelitian ini berusaha untuk menemukan perbedaan baru untuk memahami otonomi daerah melalui deskripsi atas proses dilaksanakannya otonomi daerah dalam konteks di Indonesia dengan mengaitkannya terhadap teori dan konsep yang ada.

Babbie (2010) menjelaskan bahwa dalam penelitian kualitatif ada suatu cara yang dilakukan untuk mengambil data tanpa mengganggu masyarakat yang diteliti. Mengganggu dalam artian karena dalam melakukan penelitian kualitatif terkadang peneliti perlu terjun langsung ke lapangan dan masuk ke dalam interaksi atau proses dari objek yang diteliti tersebut. Sehingga, menurut Babbie (2010) ada cara lain yang bisa dilakukan untuk melakukan penelitian kualitatif tanpa harus mengganggu objek yang diteliti (unobstrusive research), salah satunya dengan melakukan konten analisis. Babbie (2010) juga menjelaskan bahwa dalam melakukan konten analisis, sumber datanya bisa berasal dari buku, majalah, koran, halaman di internet, puisi, lagu, pidato, surat, pesan elektronik dan lain sebagainya. Pada tulisan ini, untuk memahami otonomi daerah yang terjadi di Indonesia, maka dipergunakan konten analisis untuk menganalisis dokumen-dokumen dan kajian teori atas pelaksanaan otonomi daerah di Indonesia.

\section{HASIL DAN PEMBAHASAN}

Untuk memahami bagaimana institusi pemerintahan di Indonesia menjalankan konsep dan ide terkait dengan demokrasi dan otonomi daerah. Pada tulisan ini akan dibahas menggunakan beberapa kerangka teori ekonomi kelembagaan yaitu berkaitan dengan biaya transaksi (transaction cost), teori kontrak, assymetric information, dan public choice theory.

Konsep Transaction Cost yang dipergunakan pada tulisan ini adalah biaya yang muncul akibat adanya suatu transaksi (Coase, 1937; Rindfleisch, 2020). Teori ini muncul akibat adanya penelaahan mengapa bisa muncul suatu perusahaan dalam sistem perekonomian. Berdasarkan hasil penelusuran yang dilakukan oleh Coase (1937), diketahui bahwa ada biaya-biaya di luar proses produksi untuk menghasilkan suatu barang atau jasa (Coase, 1937). Biaya transaksi yang dimaksud adalah biaya yang keluar akibat adanya keperluan untuk memastikan bahwa hak dan kewajiban dari pihak-pihak yang terlibat dalam transaksi terlindungi (Rindfleisch, 2020). Kegiatan yang dilakukan untuk menjaga hak dan kewajiban tersebut lah yang disebut dengan biaya transaksi. Aksi yang dilakukan untuk menjaga hak dan kewajiban tersebut salah satunya dilakukan dengan disusunnya suatu kontrak. Ketika kontrak itu disusun, bukan tanpa mengeluarkan biaya (Coase, 1937). Namun ada juga biaya yang muncul. Selain itu, ada juga biaya yang hadir untuk memastikan bahwa pelaksanaan transaksi sudah sesuai dengan apa yang ada di dalam kontrak (Coase, 1937).

Dalam ekonomi yang dimaksud dengan kontrak adalah sebuah kesepakatan yang dilakukan oleh dua pihak atau lebih yang membuat komitmen satu sama lain dalam kaitannya dengan kegiatan yang akan mereka lakukan (Brosseau, E., 2002). Kontrak muncul untuk memastikan bahwa hak-hak kepemilikan —sebagai dorongan utama dalam sistem kapitalis-bisa dijamin perlindungannya. Bila hak kepemilikan tersebut tidak diatur dan dilindungi, maka pihak-pihak yang terlibat dalam proses transaksi tersebut maka akan kehilangan motivasinya dan insentifnya. 
Akibatnya bila tidak ada jaminan tersebut, sistem perekonomian bisa tidak berjalan karena pihakpihak tersebut tidak merasa adanya keuntungan untuk saling berinteraksi akibat adanya pelanggaran terhadap hak kepemilikan mereka.

Informasi merupakan komoditas utama di era abad 20 ini. Begitu pun di dalam sistem perekonomian. Informasi yang tidak setimpang atau assymetric information merupakan sebuah kondisi di mana adanya satu pihak yang lebih memiliki informasi dibandingkan dengan pihak lainnya (Fazzari \& Variato, 1994). Akibat adanya ketimpangan informasi ini, maka salah satu pihak yang memiliki informasi yang lebih banyak memiliki insentif lebih besar untuk melakukan tindakan curang yang bisa merugikan pihak yang tidak memiliki informasi tersebut (Rubinfeld, 1377). Hak kepemilikan dia yang tidak memiliki informasi secara komplit menjadi terancam (Fazzari \& Variato, 1994; Rubinfeld, 1377; W. Kasper and M. E. Streit, 2000).

Teori Public Choice merupakan sebuah konsep yang dipergunakan untuk menggabungkan pandangan-pandangan ekonomi dalam pelaksanaan pengambilan keputusan politik (Ery, 2015). Teori ini marak dipergunakan untuk menjelaskan keputusan-keputusan yang diambil oleh pejabat pemerintahan. Salah satu perhatian utama para pemangku kekuasaan adalah bagaimana mereka bisa berkuasa kembali pada periode selanjutnya (aspek politik). Namun, terkadang keputusan politik yang diambil ini cenderung merugikan. Oleh sebab itu, untuk mengurangi implikasi negatif berupa kerugian, maka dimasukkan lah pendekatan ekonomi untuk memastikan bahwa keputusan politik yang diambil tersebut tidak hanya bisa menarik suara masyarakat saja namun juga bisa memberikan keuntungan.

Bila dilihat dari sejarahnya, pelaksanaan otonomi daerah di Indonesia dilaksanakan dengan proses yang cukup instan. 7 (tujuh) tahun pasca dilaksanakannya reformasi di Indonesia, negara langsung berusaha menerapkan konsep otonomi daerah secara langsung tanpa dibarengi dengan persiapan-persiapan pelaksanaan di daerahnya seperti apa. Sehingga permasalahan-permasalahan yang disebutkan pada poin 1 dan poin 2 ini muncul. 7 (tujuh) tahun bukan merupakan waktu yang singkat. Namun, bila sebelumnya belum dilakukan persiapan-persiapan, maka pelaksanaannya pun akan menjadi lebih sulit. Apalagi demokrasi itu hadir bukan hanya sebagai konsep atau ide saja, namun juga sebagai budaya praktik pelaksanaan. Untuk benar-benar menerapkan otonomi daerah pastinya akan memakan waktu yang tidak sedikit. Pada saat itu semangat dan urgensi pelaksanaan demokrasi di Indonesia sedang berada pada puncaknya. Namun, perubahan yang radikal tersebut secara segera menyebabkan pelaksanaannya yang kurang efektif. Seharusnya dilakukan terlebih dahulu proses-proses transisi perubahan dari sistem pemerintah terpusat menjadi otonomi daerah. Di dalam Undang-Undang yang terkait dengan pelaksanaan otonomi daerah ini, masih belum dipertimbangkan juga terkait dengan aspek peralihannya. Artinya, Undang-Undang terkait dengan otonomi daerah tersebut masuk ke dalam kategori incomplete contract karena ada hal-hal yang masih belum di atur di dalam kontrak tersebut.

Bila dilihat dari kacamata ekonomi kelembagaan, pelaksanaan dari otonomi daerah yang tergesa-gesa tersebut disebabkan karena keputusan politik untuk memenuhi permintaan masyarakat. Bila dilihat dari teori public choice, keputusan yang diambil tersebut masih kurang mempertimbangkan aspek ekonominya dan lebih berat di segi pemenuhan aspek politiknya. Dalam teori tersebut pun dijelaskan bahwa pemerintah sebagai institusi diposisikan tidak hanya untuk memenuhi target-target ekonomi saja, namun juga akan lebih mempertimbangkan aspekaspek politik agar bisa menjabat kembali di kursi kekuasaan. Dengan dilaksanakannya otonomi daerah, pemerintah daerah pun kemudian diberikan keleluasaan untuk melaksanakan desentralisasi fiskal. Keputusan atas hal inilah yang kemudian dianggap kurang dipersiapkan secara matang agar bagaimana pelaksanaan desentralisasi fiskal sebaiknya dilaksanakan agar 
target-target ekonomi bisa tercapai. Berdasarkan beberapa hasil studi terkait desentralisasi fiskal diketahui bahwa masih jarang ditemukan proses pendampingan terhadap daerah-daerah dalam melaksanakan desentralisasi fiskal tersebut. Pemerintah diminta untuk terjun langsung menangani proses-proses pembangunan di daerahnya masing-masing.

Selain itu, bila dilihat dari perspektif ekonomi kelembagaan, pelaksanaan otonomi daerah ini sebetulnya akan memerlukan dana yang cukup besar. Apalagi nantinya pada saat pelaksanaan akan timbulnya biaya-biaya transaksi untuk memastikan otonomi daerah tersebut dilaksanakan secara baik. Perihal yang belum diperhatikan juga pada saat pengesahan Undang-Undang terkait otonomi daerah itu sendiri adalah terkait dengan biaya transaksi tersebut seperti biaya yang diperlukan untuk mendampingi daerah dalam pelaksanaan desentralisasi fiskal. Biaya pendampingan ini tujuannya adalah untuk memastikan bahwa kontrak (dalam konteks ini adalah Undang-Undang Otonomi Daerah dan Pemerintah Daerah) bisa dilaksanakan dengan sebagai mana mestinya. Artinya memang ada biaya yang belum diperhitungkan pada saat diterapkannya Undang-Undang terkait otonomi daerah tersebut. Penanganan biaya yang belum diperhitungkan ini juga menjadi salah satu faktor dari lemahnya proses pelaksanaan otonomi daerah di Indonesia.

Seperti yang sudah dijabarkan sebelumnya, konsep dari demokrasi dan otonomi daerah di Indonesia merupakan konsep yang masih berkembang. Artinya masih banyak hal yang bisa ditingkatkan dari pelaksanaannya. Dalam tulisan ini akan dibahas beberapa permasalahan yang dianggap cukup krusial dalam proses demokratisasi di Indonesia serta proses pembangunan nasional, seperti: (1) kualitas sumber daya manusia; (2) kesenjangan antar daerah yang semakin tajam; dan (3) aspek politik di masing-masing daerah.

\section{Kurangnya Sumber Daya Manusia yang berkualitas di Daerah di Indonesia}

Salah satu hal mendasar yang cukup krusial dalam proses pembangunan nasional, daerah maupun desa sekalipun, adalah terkait dengan kualitas sumber daya manusia. Kondisi yang terjadi di Indonesia adalah tidak semua daerah memiliki sektor pendidikan yang berkualitas. Ada daerah yang memiliki sektor pendidikan yang bagus sekali, dan ada juga daerah yang sektor pendidikannya masih perlu banyak dukungan dari daerah lainnya. Masalah yang timbul bukan hanya dari segi infrastruktur sekolah yang kurang memadai, namun dari segi akses bagi seluruh masyarakat untuk mendapatkan pendidikan hingga ke rendahnya tingkat kesejahteraan guru yang berdampak terhadap kualitas pengajaran dan pendidikan yang diberikan.

Sumber daya manusia yang berkualitas merupakan kunci dari segala kunci untuk memajukan daerah serta negara Indonesia. Tidak peduli seberapa kaya daerah tersebut, apabila pejabat pemerintahannya tidak mampu untuk mengelola daerahnya tersebut. Maka kekayaan tersebut tidak akan memberikan dampak yang signifikan terhadap proses pembangunan maupun kesejahteraan masyarakat. Malahan yang ada dengan sumber daya tersebut malah menjadi sebuah kutukan yang menimbulkan konflik antar pihak yang ingin menguasai hal tersebut.

Hal ini pun terbukti di Indonesia. Indonesia merupakan negara yang kaya akan sumber daya alam. Segala macam sumber daya alam yang esensial bisa didapatkan di negara Indonesia. Indonesia bisa saja menutup diri untuk berdikari-walaupun sebenarnya bertentangan dengan konsep keterbukaan ekonomi yang lebih menguntungkan-apabila memang Indonesia mau. Namun dari semenjak Indonesia menjadi negara yang merdeka, Indonesia masih tidak bisa mengejar ketertinggalan dari negara lainnya yang bahkan tidak lebih dahulu merdeka dari Indonesia. Contoh klasik yang sering dijadikan sebagai acuan terkait hal ini adalah Singapura. Singapura tidak lebih dahulu merdeka dibandingkan Indonesia. Namun mereka bisa secara cepat menyusul ketertinggalan mereka dan bisa berstatus sebagai negara maju. Begitu pun juga dengan 
Korea Selatan yang di tahun 1960an masih berstatus sama seperti Indonesia. Namun, di abad 20 awal ini, Korea Selatan sudah bisa melangkah maju dibanding Indonesia dan bisa bersaing dengan negara yang lebih awal maju seperti Jepang. Hal ini membuktikan bahwa sumber daya alam bukan menjamin kesuksesan suatu negara. Namun, apabila suatu negara yang bisa sukses tanpa adanya sumber daya alam, tiba-tiba mendapatkan keberkahan sumber daya alam yang melimpah secara tiba-tiba, mungkin mereka akan semakin mendominasi di dunia global. Secara logis, seharusnya Indonesia bisa menjadi salah satu pemimpin dunia dengan sumber daya alamnya yang melimpah. Namun, hal ini tidak terjadi.

Sumber daya manusia yang ada belum mampu untuk mengelola sumber daya alam yang tersedia. Sumber daya alam sendiri sekarang telah menjadi kewenangan dari Pemerintah Daerah. Sehingga, tanggung jawab pengelolaannya pun sudah diberikan kepada daerah. Kunci keberhasilan dari pemanfaatan sumber daya alam ini tidak lain dikarenakan juga manusia yang akan mengelolanya. Lazimnya, sumber daya alam yang ada di Indonesia malah dikelola oleh negara lainnya. Akibatnya, manfaat dari sumber daya alam yang ada di Indonesia malah lebih banyak dinikmati oleh negara lain.

Selain itu, sumber daya manusia ini juga menjadi hal yang penting dalam proses administrasi pengelolaan pemerintahan serta proses pembangunan nasional dan daerah. Bila sumber daya alam tersebut bisa membantu Indonesia untuk mendapatkan kapital atau modal untuk proses pembangunan, maka langkah selanjutnya yang perlu diperhatikan adalah bagaimana proses pengelolaan pembangunannya tersebut. Modal yang tak terbatas bila tidak dibarengi dengan kemampuan untuk mengelola keuangannya secara baik-melalui proses pembangunan yang baik. Maka hasilnya akan sama saja. Pembangunan jadi tidak berjalan. Maksud dari pernyataan ini adalah walaupun modal pembangunan besar, namun jika pelaksanaan pembangunannya tidak berjalan dengan baik. Manfaatnya tidak akan diterima oleh masyarakat. Malahan yang terjadi adalah pemborosan anggaran karena uang yang dipergunakan menjadi tidak bermanfaat bagi siapa-siapa.

Minimnya pelaksanaan pembangunan yang bermanfaat di daerah ini tercerminkan dari anggaran belanja pemerintahnya. Berdasarkan Laporan dari Menteri Keuangan pada tahun 2019 lalu, diketahui bahwa rata-rata anggaran belanja pemerintah daerah (APBD) dipergunakan untuk belanja kantor, belanja pegawai dan belanja perjalanan dinas. Nilainya sendiri disebutkan bahwa bisa mencakup hingga 70\%. Artinya, hanya 30\% anggaran dari belanja pemerintah yang benarbenar dipergunakan untuk pembangunan daerahnya. Lalu, dari $30 \%$ anggaran yang termanfaatkan untuk pembangunan daerahnya pun masih bisa dipertanyakan bagaimana kualitas dari penyampaian dan pelayanannya terhadap masyarakat. Apakah masyarakat betul-betul merasakan dampaknya atau tidak. Bila pemanfaatan anggaran belanja pemerintah ini betul-betul dipantau secara ketat baik oleh auditor pembangunan maupun oleh masyarakatnya sendiri, tentunya akan terjadi perubahan yang lebih baik dalam proses pembangunan. Pun demikian, pelaksanaan proses pembangunan itu sendiri bukanlah hal yang mudah. Sehingga memang apabila Indonesia betul-betul ingin maju, garda pertama yang perlu diperkuat adalah sumber daya manusia pemerintahnya.

Ketika sumber daya manusia pemerintahnya sudah benar-benar berkualitas, penyampaian pembangunan pun akan menjadi lebih bermanfaat dan berguna. Aparatur Sipil Negara (ASN) baik yang di pusat maupun di daerah harus memiliki kualitas yang betul-betul mumpuni. Apabila proses rekrutmennya itu sendiri masih dipenuhi oleh praktik Korupsi, kolusi, dan nepotisme, tentunya proses pembangunan Indonesia di tiap-tiap daerah akan jalan di tempat. Oleh sebab itu, sangat urgen dan esensial sekali memastikan bahwa sumber daya manusia yang ada di daerah- 
terutama yang ada di pemerintahan - itu benar-benar berkualitas. Tujuannya adalah supaya proses pembangunan bisa terlaksana secara baik dan benar, Kemungkinan besar, salah satu penyebab kondisi ini yang masih sulit untuk mengejar ketertinggalan dengan negara-negara maju itu sendiri adalah disebabkan karena pemerintah di daerah belum bisa melakukan pembangunan secara paripurna. Sebelum negara berfokus pada usaha penambahan atau peningkatan pendapatan negara, seharusnya negara berfokus terlebih dahulu pada anggaran yang sudah ada. Menambah anggaran ketika yang tersedia pun sudah tersia-siakan, maka tambahan anggaran tersebut malah akan menjadi terbuang secara percuma dan kurang terasa dampaknya. Ketika sumber daya manusianya telah dididik secara berkualitas, maka nantinya secara organik usaha-usaha pendapatan negara akan bertambah.

\section{Masalah Kesenjangan Antar Daerah}

Studi yang dilakukan oleh (Sabilla \& Jaya, 2014) mengenai pengaruh dari desentralisasi fiskal terhadap pertumbuhan ekonomi per kapita regional di Indonesia juga menunjukkan bahwa terjadi hubungan yang positif antara desentralisasi fiskal dengan pertumbuhan ekonomi regional (provinsi). Dengan menggunakan data panel dari seluruh provinsi dari tahun 2006-2010, Sabilla \& Jaya (2014) menemukan bahwa rata-rata di seluruh provinsi di Indonesia terjadi hubungan yang positif antara pertumbuhan ekonomi provinsi dengan penerapan desentralisasi fiskal ini. Namun, Indonesia sendiri merupakan negara yang memiliki tingkat keberagaman yang tinggi. Dampak dari keberagaman ini adalah terjadinya kesenjangan ekonomi yang tinggi antar daerah. Kesenjangan ekonomi antar daerah dapat diukur, salah satunya, menggunakan indeks Williamson yang mengukur PDRB per kapita kabupaten/kota. Semakin tinggi nilai indeksnya, maka semakin tinggi kesenjangan ekonomi yang terjadi pada tiap daerah. Berdasarkan data PDRB per kapita kabupaten/kota pada rentang tahun 1995-2011 pada gambar 1, ditemukan terjadinya peningkatan dari tingkat kesenjangan ekonomi tiap daerah pasca berakhirnya rezim Orde Baru. Oleh sebab itu, penelitian yang akan dilakukan ini berusaha untuk mencari tahu seberapa besar efisiensi penerapan dari desentralisasi fiskal di Indonesia terhadap pertumbuhan ekonomi daerah dalam usaha untuk mengurangi kesenjangan ekonomi yang terjadi antar daerah tersebut.

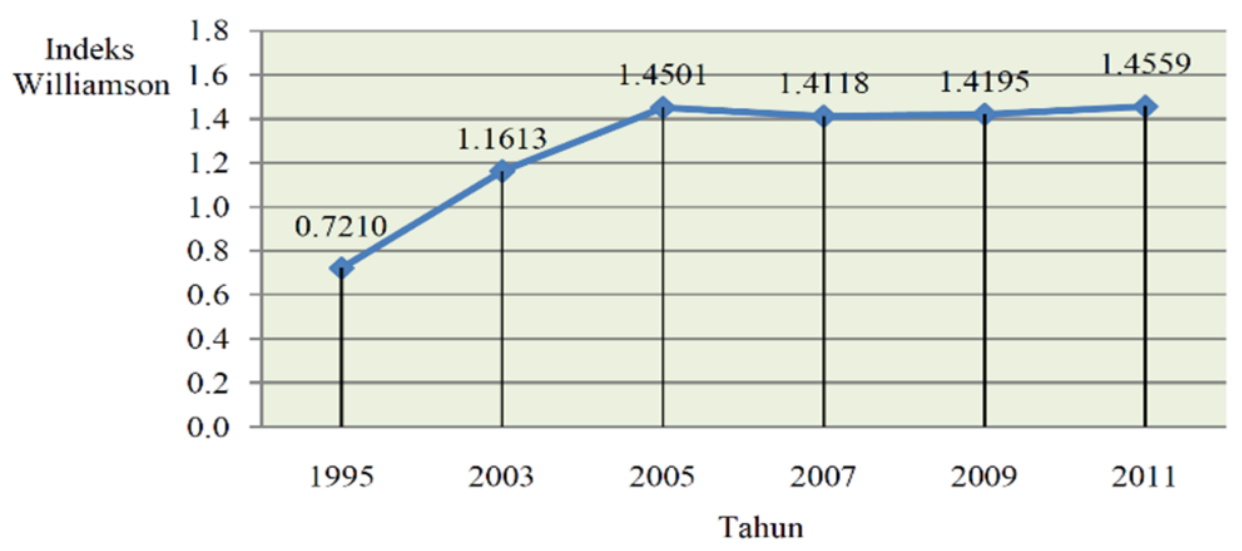

Gambar 1. Indeks Williamson PDRB per Kapita Kabupaten/Kota

Bila kita melihat penelitian yang dilakukan oleh (Sabilla \& Jaya, 2014), ditemukan bahwa desentralisasi fiskal secara rata-rata tiap provinsi bernilai positif dalam memberikan dampak terhadap pertumbuhan ekonomi masing-masing daerah. Namun, berdasarkan hasil penelitian yang dilakukan oleh menemukan bahwa kesenjangan ekonomi tiap daerah cukup tinggi. Sehingga 
dapat dipahami bahwa secara rata-rata terjadi peningkatan atas pertumbuhan ekonomi di tiap daerah. Namun ada daerah yang lebih tinggi pertumbuhannya dibandingkan dengan yang daerah lainnya. Akibatnya, walaupun secara rata-rata pertumbuhan ekonomi tiap daerah positif, tingkat kesenjangan daerah malah cenderung meningkat. Hal ini disebabkan oleh adanya daerah yang rendah pertumbuhannya dan ada daerah yang tinggi pertumbuhannya. Tingkat variasi pertumbuhan ekonomi tiap daerah sendiri terbilang cenderung cukup tinggi. Ada daerah yang sangat maju dan ada daerah yang terbelakang dan tertinggal.

Selain itu, beberapa penelitian yang mengkaji atas hubungan antara desentralisasi fiskal dengan pertumbuhan ekonomi di tingkat provinsi menunjukkan adanya daerah yang hubungannya negatif dan ada daerah yang hubungannya positif (Nurhemi, 2015). Beberapa contoh hubungan yang negatif terjadi di Provinsi Banten (Hanifah, 2018), dan Provinsi Sumatera Selatan (Bashir, 2011). Beberapa contoh hubungan yang positif antara desentralisasi fiskal dengan pertumbuhan ekonomi daerah adalah Provinsi Aceh (Anita, Said Mohammad, 2014), Provinsi Jawa Tengah (Apriesa \& Miyasto, 2013), dan Provinsi Bali (Pramandari \& Kaluge, 2017). Bahkan studi yang dilakukan oleh (Satria, 2016) menunjukkan bahwa di Jawa Timur, derajat desentralisasi fiskal mempengaruhi hubungan yang positif atau negatif terhadap pertumbuhan. Ketika derajat desentralisasi melebihi batas tertentu, (Satria, 2016) menjelaskan bahwa hubungannya terhadap pertumbuhan ekonomi daerah adalah negatif seperti yang terlihat pada gambar 2.

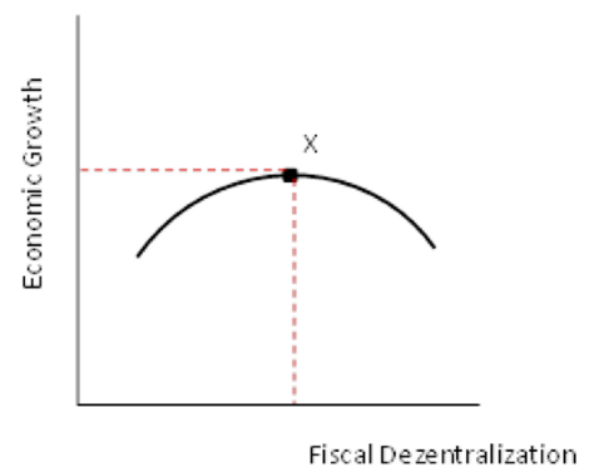

Gambar 2. Hubungan Desentralisasi Fiskal dengan Pertumbuhan Ekonomi (Hump-Shaped)

(Satria, 2016)

Dari hasil-hasil penelitian yang sudah dilakukan sebelumnya ini ditemukan bahwa meskipun secara agregat nasional hubungan antara desentralisasi fiskal dengan pertumbuhan ekonomi ratarata per daerah adalah positif, namun perlu dilakukan penelitian lebih mendalam lagi terhadap hubungan masing-masing per daerah tersebut. Hal ini dikarenakan adanya dampak dari hubungan tersebut cukup beragam baik dari segi bentuk hubungannya (negatif/positif) juga dari segi besaran hubungannya (tinggi/rendah). Terlebih lagi adanya studi yang menunjukkan bahwa pada level tertentu desentralisasi fiskal malah akan memberikan hubungan yang negatif terhadap pertumbuhan ekonomi. Oleh sebab itu, perlu diteliti lebih lanjut lagi mengenai derajat besaran desentralisasi fiskal yang ideal terhadap pertumbuhan ekonomi.

\section{Masalah Sinkronisasi Agenda Pembangunan Pusat dan Daerah}

Semenjak diberlakukannya Undang-Undang yang berkaitan dengan otonomi daerah tersebut, Pemerintah Pusat tidak memiliki kewenangan secara luas untuk mengelola pembangunan yang dilakukan di daerah. Pembangunan yang dilakukan di daerah akan menjadi kewenangan dari 
Pemerintah Daerah. Prinsip dari pelaksanaan yang dilaksanakan seperti ini adalah dikarenakan pada dasarnya proses pembangunan selayaknya dijalankan oleh mereka yang akan menerima manfaatnya secara langsung. Skema client-patron terkadang kurang memberikan dampak yang signifikan terhadap masyarakat karena yang betul-betul mengetahui permasalahan atas suatu isu di tempatnya adalah mereka sendiri. Pemerintah sebagai pelaksana pembangunan sebetulnya lebih memiliki keahlian dalam hal memberikan opsi-opsi solusi yang bisa ditawarkan untuk memecahkan masalah. Sedangkan si masyarakat sendiri lah yang tahu masalah yang dihadapi itu persisnya seperti apa. Ketika solusi yang ditawarkan tidak sesuai dengan apa yang menjadi permasalahan. Inilah yang kemudian sering ditemukan di lapangan di mana program yang dibuat oleh pemerintah tidak tepat sasaran atau bahkan tidak mampu untuk menyelesaikan masalah. Karena pemerintah sendiri pun tidak memiliki informasi persisnya seperti apa.

Berdasarkan sudut pandang dari paradigma ekonomi kelembagaan, hal yang terjadi tersebut disebabkan karena adanya assymetric information. Assymetric Information ini terjadi karena informasi yang ada di daerah tidak dimiliki oleh diketahui oleh pemerintah pusat. Karena informasi yang tersedia itu jumlahnya bisa tak terbatas, sulit sekali bagi pemerintah pusat untuk benar-benar bisa menangkap keseluruhan informasi yang tersedia di daerah guna menyiapkan proses pembangunan yang efektif dan efisien. Biaya transaksi yang diperlukan untuk menangkap keseluruhan informasi ini tentunya tidak murah. Assymetric Information ini lah yang kemudian menjadi semangat dilaksanakannya pembangunan oleh pemerintah daerah. Karena pemerintah pusat yang tidak memiliki informasi menyeluruh atas permasalahan yang ada di daerah, maka akan lebih tepat apabila daerah sendiri lah yang menyelesaikan permasalahannya. Namun, yang menjadi kendala adalah kadang kala pemerintah daerah ini belum disediakan amunisi-amunisi berupa solusi program pembangunan yang tepat akibat minimnya pengalaman dan keahlian. Akibat kurangnya pendampingan atas peralihan pelaksanaan sistem pemerintahan terpusat menjadi otonomi daerah.

Selain itu, permasalahan yang kemudian muncul juga adalah terkait dengan sinkronisasi dan integrasi kebijakan maupun pembangunan yang dilakukan oleh pemerintah pusat dengan yang dilakukan oleh pemerintah daerah. Salah satu eksternalitas dari diterbitkannya undang-undang terkait otonomi daerah ini adalah bahwa adanya ketidakharmonisan antara perencanaan serta pembangunan yang dilakukan oleh Pemerintah Pusat dengan Pemerintah Daerah akibat jabatan pimpinan di daerah itu merupakan jabatan politis. Dalam konteks ini terjadi masalah agency problems (principal-agent) di mana dengan diterbitkannya Undang-Undang Otonomi Daerah, pemerintah pusat sebagai principal yang mendelegasikan proses pembangunan ini di daerah kepada Pemerintah Daerah sebagai agent. Namun, dalam pelaksanaannya timbul permasalahan karena terjadi ketidakserasian antara pemerintah pusat dengan pemerintah daerah dalam pelaksanaan pembangunannya. Karena untuk menarik suara dari masyarakat agar bisa terpilih kembali pada saat dilaksanakan Pilkada, maka yang sering terjadi adalah kebijakan yang diambil oleh para pemimpin di darah itu adalah kebijakan politis. Sering kali, kebijakan-kebijakan politis yang diambil tersebut tidak sejalan dengan tujuan pembangunan nasional. Sehingga terjadi disharmonisasi antara tujuan yang dilakukan oleh pemerintah pusat dengan pemerintah daerah.

\section{SIMPULAN}

Berdasarkan beberapa hal tersebut, diketahui bahwa dalam pelaksanaan otonomi daerah sebagai bentuk semangat demokratisasi di Indonesia ada beberapa masalah seperti ketidaksiapan dari segi sumber daya manusia, ketimpangan antar daerah, pelaksanaan yang terburu-buru, dan disharmonisasi pelaksanaan pembangunan antara pemerintah pusat dengan pemerintah daerah. 
Untuk itu ada beberapa rekomendasi yang bisa diberikan untuk menunjang pelaksanaan dari otonomi daerah tersebut yaitu: 1) Mengutamakan proses rekrutmen di Pemerintahan Daerah yang transparan dan dengan standar yang tinggi agar bisa menarik sumber daya manusia yang berkualitas bisa berperan banyak dalam pengelolaan administrasi pemerintahan (termasuk proses perencanaan dan pembangunan daerahnya). Selain itu, diperlukan juga mekanisme insentif yang lebih baik sehingga SDM terbaik dan berkualitas di Indonesia mau bergabung dengan pemerintah. Selain itu, perlu juga dilakukan peningkatan citra dari pemerintah agar SDM berkualitas tersebut mau bergabung dengan pemerintah. Karena sering kali, SDM berkualitas yang ada di Indonesia lebih senang bergabung dengan pihak swasta ketimbang dengan pihak pemerintah. Padahal pihak pemerintah lah yang betul-betul membutuhkan SDM berkualitas tersebut guna pelaksanaan pembangunan nasional dan daerah. Dengan adanya dukungan sumber daya yang berkualitas tersebut, ke depannya, diharapkan pembangunan bisa lebih efektif dan efisien. Sehingga anggaran yang telah diposkan ke daerah bisa betul-betul termanfaatkan untuk kesejahteraan masyarakat melalui pelaksanaan program-program yang berkualitas. 2) Melakukan pendampingan kepada daerah secara seksama untuk memastikan bahwa pelaksanaan dari pembangunan bisa berjalan dengan lancar. Tidak semua daerah memiliki kondisi yang sama di Indonesia. Ada daerah yang sudah maju dan ada daerah yang masih butuh pendampingan lebih lanjut. Sehingga, penerapan otonomi daerah secara serentak tanpa memperhatikan kondisi dari masing-masing daerah tersebut bisa meminimalisir eksternalitas nya . Selain itu, tujuan dari pendampingan ini bertujuan tidak hanya untuk mengurangi eksternalitas tersebut, namun juga untuk menyinkronkan pembangunanpembangunan yang dilakukan di daerah maupun dengan tujuan pembangunan yang dicanangkan oleh Pemerintah Pusat. Apabila daerah terus berjalan secara masing-masing, maka semangat dari demokrasi itu sendiri akan hilang. Karena dengan adanya demokrasi itu sendiri seharusnya bisa disesuaikan antara kebutuhan yang ada di daerah dengan tujuan pembangunan nasional.

\section{DAFTAR PUSTAKA}

Anita , Said Mohammad. (2014). PENGARUH DESENTRALISASI FISKAL TERHADAP PERTUMBUHAN EKONOMI DI PROVINSI ACEH. Jurnal Ilmu Ekonomi, 2(3), 21-29.

Apriesa, L. F., \& Miyasto. (2013). Pengaruh Desentralisasi Fiskal terhadap Pertumbuhan Ekonomi Daerah dan Ketimpangan Pendapatan (Studi Kasus: Kabupaten/Kota di Jawa Tengah). Diponegoro Journal of Economics, 2(1), 1-12. https://ejournal3.undip.ac.id/index.php/jme/article/view/1916/1914

Aspers, P., \& Corte, U. (2019). What is Qualitative in Qualitative Research Content courtesy of Springer Nature, terms of use apply . Rights reserved . Content courtesy of Springer Nature, terms of use apply . Rights reserved . Springer, February, 139-160.

Babbie, E. R. (2010). The Basics of Social Research. Cengage Learning.

Bashir, A. (2011). Dampak Desentralisasi Fiskal Terhadap Perekonomian Daerah Kabupaten/Kota Di Provinsi Sumatera Selatan. KAjian Ekonomi, 10(2), 1-35.

Brosseau, E., \& G. (2002). The Economics of Contract-Theories and Applications. Cambridge University Press.

Bryman, A. (1988). Quantity and Quality in Social Research. 
Coase, R. H. (1937). The Nature of the Firm. Economica, 4(16), 386-405. https://doi.org/10.1111/j.1468-0335.1937.tb00002.x

Ery, F. (2015). An Economic View on Politics : Public Choice Theory Turkey at the Beginning of 21 st Century: Past and Present Editors. Bulgaria: Sofia University St. Kliment Ohridski Publishing, June 2015, 367-381.

Fazzari, S. M., \& Variato, A. M. (1994). Asymmetric Information and Keynesian Theories of Investment. Journal of Post Keynesian Economics, 16(3), 351-370. https://doi.org/10.1080/01603477.1994.11489990

Hanifah, L. (2018). Analisis Pengaruh Desentralisasi Fiskal terhadap Pertumbuhan Ekonomi dan Ketimpangan Wilayah per Kabupaten/Kota di Provinsi Banten Tahun 2011-2016. Jurnal UIN Sunan Kalijaga Yogyakarta.

Negara, L. A. (2015). Telaah Isu-Isu Strategis Desentralisasi dan Otonomi Daerah.

Nurhemi, G. S. (2015). Terhadap Pertumbuhan Ekonomi. Dampak Otonomi Keuangan Daerah Terhadap Pertumbuhan Ekonomi Di Indonesia, 183-206.

Pramandari, Y., \& Kaluge, D. (2017). Desentralisasi Fiskal Dan Pertumbuhan Ekonomi Kabupaten/ Kota Di Provinsi Bali. Media Trend, 12(1), 24-34. https://doi.org/10.21107/mediatrend.v12i1.2633

Rindfleisch, A. (2020). Transaction cost theory: past, present and future. AMS Review, 10(1-2), 8597. https://doi.org/10.1007/s13162-019-00151-x

Rubinfeld, R. S. P. dan D. L. (1377). Microeconomics (8th ed.). Pearson Education, Inc., publishing as Prentice Hall.

Sabilla, K., \& Jaya, W. (2014). Pengaruh Desentralisasi Fiskal Terhadap Pertumbuhan Ekonomi Per Kapita Regional Di Indonesia. JESP: Jurnal Ekonomi \& Studi Pembangunan, 15(1), 12-22. https://doi.org/10.18196/jesp.15.1.1233

Satria, A. B. (2016). Pengaruh Derajat Desentralisasi Fiskal Terhadap Pertumbuhan Ekonomi Kabupaten/Kota Provinsi Jawa Timur Tahun 2004-2013. UNIVERSITAS AIRLANGGA.

W. Kasper and M. E. Streit. (2000). Threaten Economic Disaster (Issue December 1999). Blackwell Publishers. https://sci-hub.se/https://doi.org/10.1111/1468-0270.00197 